\title{
Challenges to Food Security in a Changing World
}

\author{
Walter E.L. Spiess
}

\begin{abstract}
The next decades will see dramatic climatic changes and a pronounced population growth Asia - accompanied by the formation of huge human agglomerations, megacities - followed by increasing numbers of people in Africa, Latin America and the Caribbean; North America and Oceania will experience a moderate population growth whereas the EU will face a shrinking population. Unfortunately regions with the highest population growth are those were most people are living in precarious conditions especially in SS Africa and to some extent in South East Asia. To feed the 9 billion people any effort has to be undertaken to utilize and exploit the available resources in a sustainable way and to minimize the interventions into the environment. Factors of relevance are competitive biofuel production, the extension of the Food Chain into the Mega-City household, minimizing of food losses by applying new communication systems and supporting Food Sovereignty efforts of Developing countries.
\end{abstract}

Keywords Climate change - Population growth - Food Security - Growth of agricultural production - World Fruit and Vegetable Production - Source of caloric food intake $\cdot$ Consumption $\cdot$ Global beverage market

\section{Introduction}

The coming decades pose a multitude of problems to the global community. The most prominent challenge to be faced is certainly increasing demand for food given the increasing world population; however new technological and socials developments also have to be addressed by politics, science, and commerce.

To Rose-for her lifelong dedication to support and promote global understanding

W.E.L. Spiess $(\bowtie)$

Institute of Food Process Engineering, Karlsruhe Institute of Technology, Kaiserstr. 12, 76128 Karlsruhe, Germany

e-mail: rose-walter.spiess@t-online.de

(C) The Author(s) 2016

P. Jackson et al. (eds.), Eating, Drinking: Surviving,

SpringerBriefs in Global Understanding, DOI 10.1007/978-3-319-42468-2_7 
Competent forecasts anticipate that the most pronounced population growth will occur $\beta$ Asia followed by Africa, Latin America, and the Caribbean; North America and Oceania will experience a moderate growth whereas Europe will face a shrinking population. The population growth especially in East Asia, India, and South West Africa will be accompanied by the formation of huge human agglomerations resulting in megacities. For example, it is expected that in China alone over 220 cities with over one million inhabitants will be formed.

Accompanying growing economic prosperity especially in Asia, a broad middle class will be formed which is likely to adopt general lifestyle values of highly industrialized countries increasing its demand for food including meat-intensive diets. Population patterns of the next decades will also be characterized by growing segments of elderly people in developed industrialized countries and large numbers of younger people in developing and emerging countries. This situation may lead to precarious conditions especially in Sub-Saharan Africa.

It is a well-based assumption that the growing world population can be supplied with sufficient quality food at least to 2050 , but present climates may undergo rather negative changes with adverse impacts on agricultural production. To feed two to three billion more people will require not only an extension but also an upgrading of the present share of farmland for food production. Furthermore, higher productivity of the agricultural sector is necessary and requires amongst other factors fertilizing already highly stressed soils, improving irrigation systems, and developing plant materials which are adapted to changing environmental conditions including less water. In producing the required amount of food, the global and local ecosystems are likely to be further compromised negatively impacting biodiversity and hastening climate change.

The efforts, however, to produce sufficient food for 10 billion people who every day require 3000 calories — on an average base — will likely not be enough. It will be important to make the food available at the place of demand. Clearly the production centers are, with regard to location and time, not congruent with the centers and times of demand forcing food to cross country frontiers and social frontiers and to be stored. This requires that major amounts of food have to be shelf stable to allow for long transport times and to compensate for times of underproduction. In addition, these more technological requirements demanded for food have to be affordable and meet social, cultural, religious, and physiological requirements and needs.

Optimistically, many of the above requirements can be met, delivered by the agricultural and food science sector. However, the basic parameters and surrounding conditions are largely political requiring those in charge to act responsibly taking into account political class and global and local social movements. Given that the scientific community is not in a position to coordinate political actions, regulate production, or provide incentives, the scientific community can point to problems and recommend solutions. In this exposé some aspects of the present day food supply chain together with some projections into the future are presented together with some thoughts as to what may impair the global provision of food. The data in most cases represent average values over rather broad data sets, and, therefore, the picture drawn is very general and requires further detailed analysis. 
Furthermore, some facts with an impact on the global food supply are discussed from a food science or more precise food engineering point of view. The material offered is far from complete but may help to understand and explain problems facing humanity.

\section{Food Availability and Food Sovereignty}

In his book, The Population Bomb, published in 1968, Paul R. Ehrlich wrote, "The battle to feed all of humanity is over. In the 1970s hundreds of millions of people will starve to death in spite of any crash programs embarked upon now. At this late date nothing can prevent a substantial increase in the world death rate....".

Although Ehrlich's scenario did not materialize, the question as to whether global agriculture can be in a position to feed the 8 to 9 billion people expected in the coming decades is today being asked in a different way. It is well understood that there will be - based on a statistical average - enough food available to feed up to 10 billion people. Therefore, the question is, "Is it possible to distribute the resources in a way that Global Food Security can be achieved not only in the privileged parts of the globe but also in the disadvantaged parts of the globe."

According to the World Food Summit in 1996 (FAO 1996), food security exists when "all people, at all times, have physical and economic access to sufficient, safe and nutritious food to meet their dietary needs and food preferences for a healthy and active life." In this definition, emphasis is obviously on "all people." From Table 1, during the late 1970s the Calorie supply steadily increased, and in the early 1980s the threshold of a minimum caloric intake of $2500 \mathrm{kcal}$ was, on average, surpassed again. Although data from other sources are not exactly congruent-a general observation which is even true for data regarding the earth surface - the tendency in all data sets points in the same direction. A more detailed and differentiated picture reveals, however, that presently Sub-Saharan Africa (SS Africa) is still below the $2500 \mathrm{kcal}$ threshold level and in South Asia also millions of people do not enjoy an adequate food supply. In 2015 hunger hotspots in Africa were identified in Angola, Namibia, Zambia, United Republic of Tanzania, Madagascar and in neighboring countries in Asia including Tajikistan, Democratic People's Republic of Korea, and, with some restrictions, India (Table 1 and Fig. 1). It is feared that especially in SS Africa food insecurity will persist beyond the next decade.

The catastrophic situation for large contingents of the global population is rooted in many factors including poverty in countries with an adequate food production (which is the case to some extent in South East Asia), lack of education in countries with an underdeveloped infrastructure, and/or poorly developed agricultural systems. In many cases, each of these situations may be traced back to total failure of the responsible national governments and international institutions to cope with the critical situations. In only a very few cases can food insecurity situations be 
Table 1 Hotspots of malnutrition: food availability/consumption (kcal per capita per day)

\begin{tabular}{l|l|l|l|l|l|l}
\hline Region & $\begin{array}{l}1964- \\
1966\end{array}$ & $\begin{array}{l}1974- \\
1976\end{array}$ & $\begin{array}{l}1984- \\
1986\end{array}$ & $\begin{array}{l}1997- \\
1999\end{array}$ & 2015 & 2030 \\
\hline World & $\mathbf{2 3 5 8}$ & $\mathbf{2 4 3 5}$ & 2655 & 2803 & 2940 & 3050 \\
\hline Developing countries & $\mathbf{2 0 5 4}$ & $\mathbf{2 1 5 2}$ & $\mathbf{2 4 5 0}$ & 2681 & 2850 & 2980 \\
\hline $\begin{array}{l}\text { Near East and North } \\
\text { Africa }\end{array}$ & $\mathbf{2 2 9 0}$ & 2591 & 2953 & 3006 & 3090 & 3170 \\
\hline Sub-Saharan Africa & $\mathbf{2 0 5 8}$ & $\mathbf{2 0 7 9}$ & $\mathbf{2 0 5 7}$ & $\mathbf{2 1 9 5}$ & $\mathbf{2 3 6 0}$ & 2540 \\
\hline $\begin{array}{l}\text { Latin America and the } \\
\text { Caribbean }\end{array}$ & $\mathbf{2 3 9 3}$ & 2546 & 2689 & 2824 & 2980 & 3140 \\
\hline East Asia & $\mathbf{1 9 5 7}$ & $\mathbf{2 1 0 5}$ & 2559 & 2921 & 3060 & 3190 \\
\hline South Asia & $\mathbf{2 0 1 7}$ & $\mathbf{1 9 8 6}$ & $\mathbf{2 2 0 5}$ & $\mathbf{2 4 0 3}$ & 2700 & 2900 \\
\hline Industrialized countries & 2947 & 3065 & 3206 & 3380 & 3440 & 3500 \\
\hline Transition countries & 3222 & 3385 & 3379 & 2906 & 3060 & 3180 \\
\hline
\end{tabular}

${ }^{\mathrm{a}}$ Excludes South Africa

Figures below $2500 \mathrm{kcal}$ per capita per day are in bold Source Alexandratos and Bruinsma (2012)

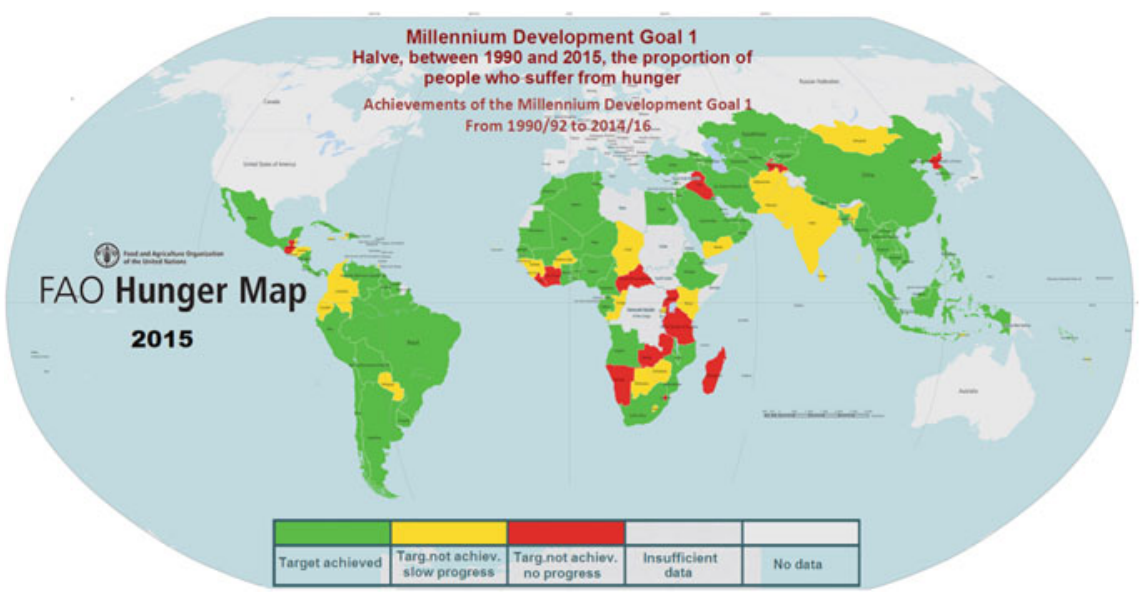

Fig. 1 Hunger Hotspots 2015. Source http://www.fao.org/fileadmin/templates/hunger-map/ images/FAO_HUNGER_MAP_2015_sm.jpg (Accessed: 2016-04-10)

attributed to climatic factors or factors which are not under control of local or regional authorities.

The expected overall positive development in the provision of food is based on the fact that the growth rates of agricultural production have surpassed the population growth rates, Fig. 2.

However, adequate caloric provision of food is a requirement that, in itself, is not sufficient. It is equally important to provide a well balanced diet. The 
Fig. 2 Population and cereal World population and Cereal Production production growth rates. Source Alexandratos and Bruinsma (2012), http://esa. un.org/unpd/wpp/ publications/files/key_ findings_wpp_2015.pdf (Accessed: 2016-04-10)

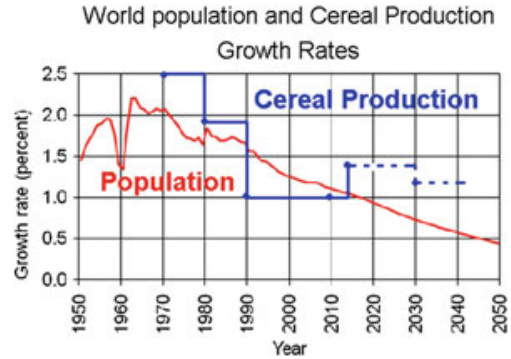

recommendations for a healthy diet are globally valid, for any cultural situation, and can be adapted to any catering situation. The demand and the availability of food will certainly differ from continent to continent, from country to country. However, for a rough estimation, some average figures can provide further insight into the availability of different types of food demanded and consumed. The data for the present situation and the projections for the future (2030) indicate, for example, that especially the developing countries and to some extent the transition countries have a higher demand for food and feed than they are producing.

It should be mentioned that the "Demand" data in Table 2 include losses and waste which amount to roughly 20-30\%, and therefore these are "low" estimates. Intelligent processing and handling and utilization of currently underutilized product and components as feed or even as food could help to reduce the "Demand" considerably and result in saving natural resources.

As illustrated in Fig. 3 for wheat and in Table 2 for important food items, the Developing Countries rely on imports for most staple foods, mainly from the developed countries. In the case of wheat it is expected that the trade deficit will grow from the present 22-25\%. Similar developments are expected for coarse grains, fresh milk, and dairy products. However, beef and veal, mutton and lamb, pig meat, and pulses for the Developing Countries rely significantly on imports from industrialized countries and to some extent from Transition Countries. For paddy rice, roots and tubers, and oilseed the group of Developing Countries can be considered self-supporting.

This separation of the production centers from centers of demand does however not only exist on a global macro-scale (transport from developed/transitional countries to developing countries) it also exists at a micro-scale between agricultural production centers in developing/transition countries (e.g., China, Brazil) and huge agglomerations of a million people within those countries. Long supply chains especially in the case of perishable produce like fruit and vegetable are prone to severe losses; despite considerable progress in produce/product stabilization supply chains are a true challenge to food science and technology. Sterile long distance bulk transports of liquids and pastes or in-city indoor agriculture are some of the revolutionary solutions which point to new horizons.

This situation certainly will prevail over the present time horizon. Considering the population growth in Developing Countries, it is expected that in the 


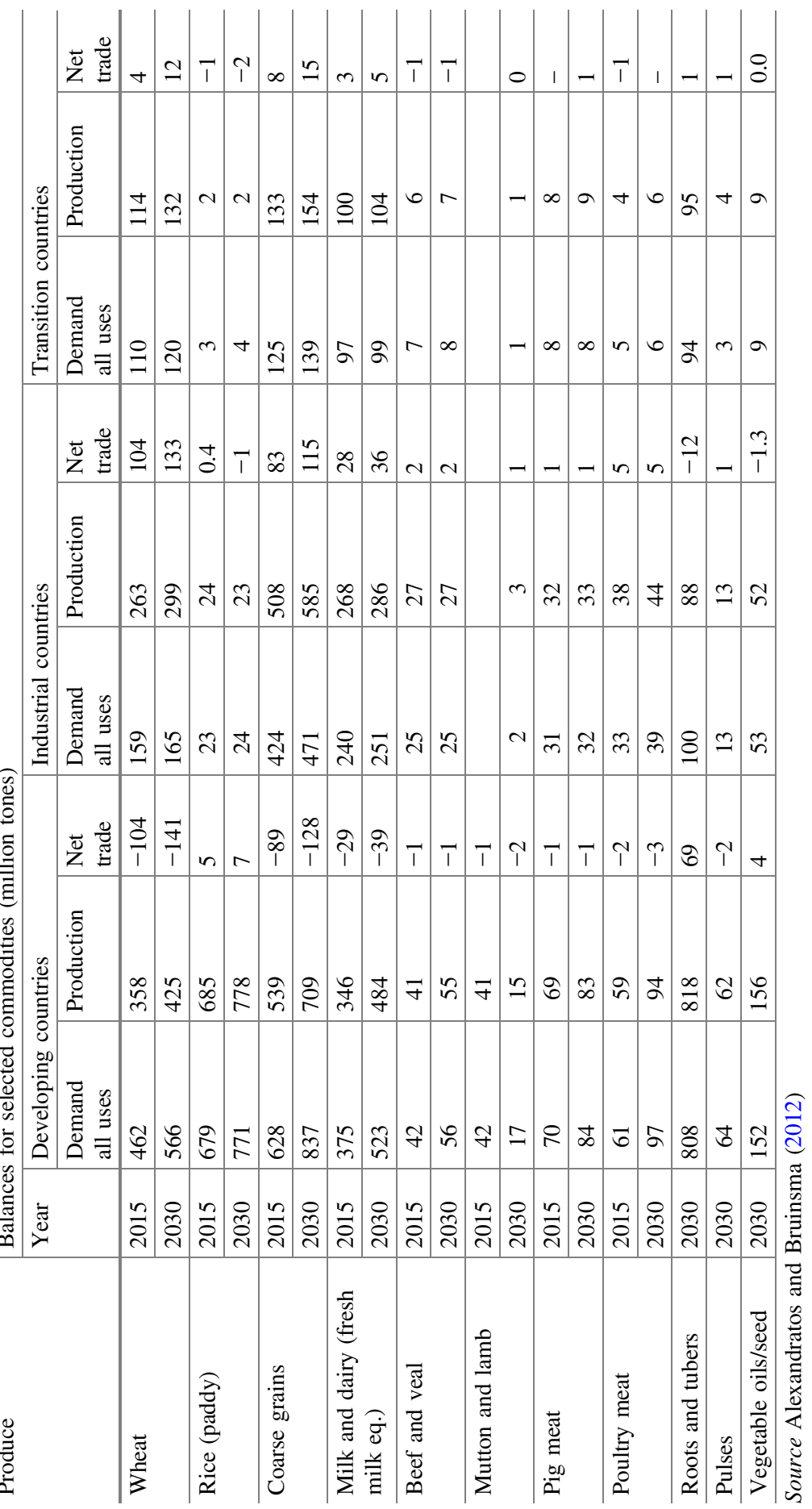


Fig. 3 Production balance of wheat. Source Alexandratos and Bruinsma (2012)

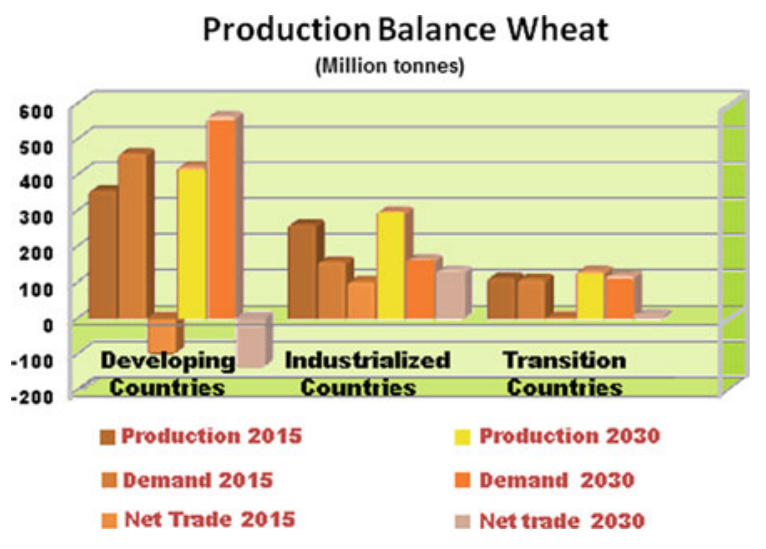

Fig. 4 Source of caloric intake. Source Alexandratos and Bruinsma (2012)

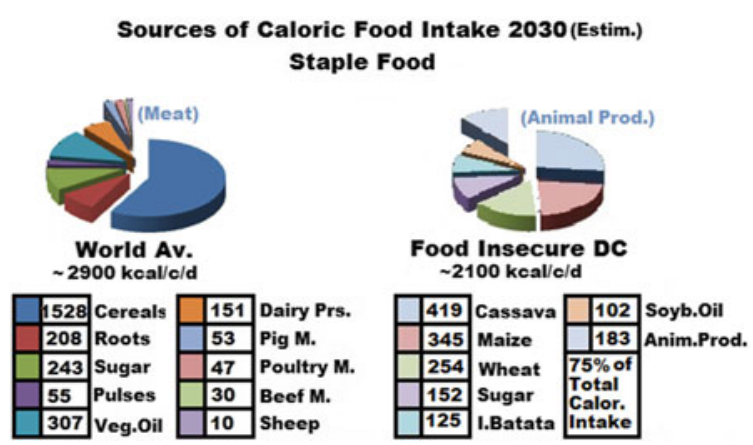

foreseeable future Developing Countries will not gain desired food sovereignty. On the contrary, the dependence on imports from developed countries will most probably grow.

\section{The Daily Intake ${ }^{1}$}

As mentioned above it is estimated (Table 1) that in 2030, on average, globally the threshold level of $2500 \mathrm{kcal} /$ person/day is surpassed. When the anticipated figures on the available feedstock (Table 2) are broken down into virtual consumption data [kg/person/year] a more detailed [kcal/person/day] virtual meal-referred to as Standard Diet in this exposé - can be composed. That analysis can reveal details of the daily energy provision of approximately $3000 \mathrm{kcal} /$ person/day. In 2030 less privileged areas especially in Africa will face a deficient food supply to $2100 \mathrm{kcal} /$ person/day and consequently malnutrition (Fig. 4).

\footnotetext{
${ }^{1}$ http://www.hsph.harvard.edu/nutritionsource/healthy-eating-plate/
} 
Fig. 5 Intake of macronutrients with reference to TE (Total Energy). SFA

Saturated Fatty Acid, PUFA

Polyunsaturated Fatty Acid, $T$ Carb Total Carbohydrates, DF Dietary Fiber, Ref. sugars Refined Sugars, Prot Protein, $B W$ Body Weight

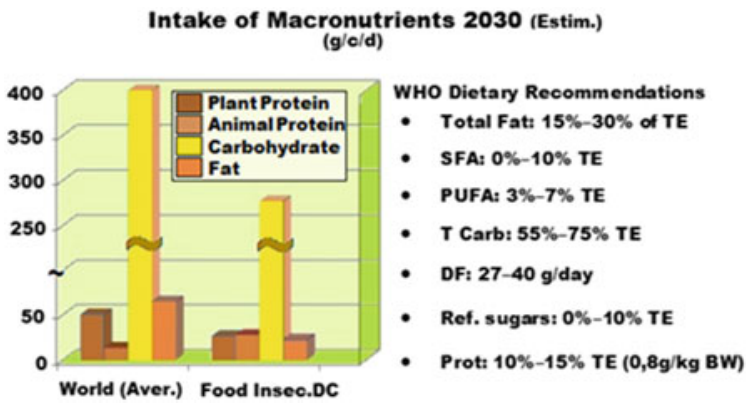

The major component in the virtual meal is carbohydrates as important sources of energy (e.g., cereals, roots and tubers, and sugar) which are available to the majority of the global population. To some extent those products are also valuable sources of proteins and minerals (Fig. 5).

\section{Important Sources of Energy-Carbohydrates}

\section{Cereals}

The major supplies of carbohydrates are cereals. For many years the most important cereal is maize (corn) which constitutes together with other coarse cereals about $45 \%$ of the world cereal production; wheat has a share of $28 \%$; and paddy rice has a share of $27 \%$. Cereals are being used for a great variety of products. In addition to providing the major energy source in human nutrition, carbohydrates are used as animal feed and feedstock for many chemical products like alcohol or plastics. Maize is used in traditional ways of consumption including breakfast cereal, popcorn, corn oil, and corn syrup production. Similar to other starch-containing produce, corn flour/starch is used as thickener in all types of food preparations.

Wheat is the main cereal in bread. Wheat flour is also the basis for pasta production, is an important breakfast cereal, and wheat germ is used for oil production. Rice is prepared in a multitude of forms and dishes, mainly as parboiled, pre-cooked, cooked or steamed, as porridge, cake or pudding, and noodles. By genetic modification, rice is enriched in Beta-Carotene (Pro-Vitamin A) to compensate for Vitamin A deficiency, a problem under which millions of people in East Asia are suffering.

Barley, a coarse grain, is the most important raw material for worldwide beer production. Other cereals suitable for the production of beer and other alcoholic beverages are maize, wheat, rice, and millet (see also Fig. 8). 


\section{Roots and Tubers}

In addition to cereals, roots, and tubers are also a very important pillar in the world's food supply. Approximately half the global production of roots and tubers is destined for human consumption, the remaining half is used as animal feed, production of starch for various purposes, production of ethyl alcohol, and industry products of various nature. The group comprises five major crops: cassava, sweet potato, potato, yams, and taro. Roots and tubers are all rich in starch but low in proteins. Cassava, sweet potato, potatoes, and yams contain modest amounts of vitamins and minerals. Because of their rather poor shelf life, they are in general processed quickly after harvest into a variety of preparations, including boiled, fried, fermented, and, as flour, in the form of porridge and finally as beer. The cassava tuber contains small amounts of cyanides which have to be removed before consumption by grating, fermenting, drying, and roasting, a process which is not required in the case of modern sweet varieties.

\section{Building the Body: Proteins}

Proteins are indispensable to any human diet. It is estimated that a healthy adult person, on average, requires about $0.8 \mathrm{~g} / \mathrm{kg}$ body weight (BW). The main sources of protein in the standard diet are cereals with about $50 \mathrm{~g} /$ person/day. Plant derived proteins should be (but there are exceptions in case of special plant protein combinations) complemented by proteins of animal origin to provide the necessary amount of essential amino acids. Meat and dairy products contribute in the standard, balanced diet about $30 \mathrm{~g} /$ person/day.

With increasing global economic growth and income, the demand for meat increased and meat production grew disproportionately. However, the rather high growth rates especially in Developing Countries in the 1980s and 1990s have not been maintained at the start of the 21 st century primarily because of a slowdown of the world economy. The production growth rates for meat are, however, still almost twice as high as the growth rates of cereals. The main consumers of meat are the growing middle class in Developing Countries especially in China and India, where consumers are turning away from plant-based traditional diets to higher meat consumption (Fig. 6). These changes in dietary habits not only have an impact on the environment - raising animals especially cattle is associated with the production of methane-but stresses the availability of cereals because animal production is mainly based on cereal such as soy feed (Tables 3 and 4). For ruminants, pasture feeding contributes also to the production of meat.

The large amounts of cereals required for the production of meat and dairy products are the reason for their high Virtual Water Footprint (VWF) compared to the VWF of cereals and vegetable produce. The high VWF of animal products stresses to a high degree the scarce water resources especially in developing counties. 

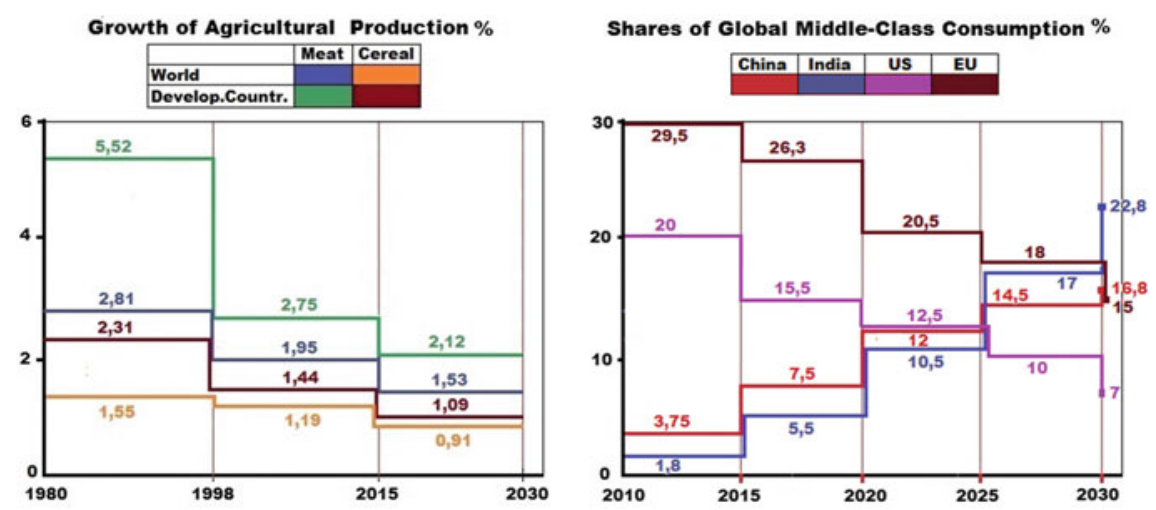

Fig. 6 Growth of agricultural production versus development of middle-class consumption. Source Alexandratos and Bruinsma (2012)

Table 3 Amount of plant-based feed to produce meat

\begin{tabular}{l|l|l|l|l}
\hline Animal & Beef & Sheep & Pig & Chicken/Turkey \\
\hline $\begin{array}{l}\text { Amount of cereal/soy feed }[\mathrm{kg}] \text { to produce } 1 \\
{[\mathrm{~kg}] \text { of meat (FCR) }}\end{array}$ & $5-16$ & $3-6$ & $3-6$ & $3-4$ \\
\hline
\end{tabular}

The FCRs (Feed Conversion Ratio) presented in the literature differ considerably depending on the background and interests of the sources; objective reasons are especially the quality of the feed Source http://www.beefusa.org/CMDocs/BeefUSA/Resources/cc2012-Beef-Feed-Efficiency-DanShike.pdf, https://en.wikipedia.org/wiki/Feed_conversion_ratio (Accessed: 2016-04-10)

Table 4 Water footprint $\left(\mathrm{m}^{3} / \mathrm{ton}\right)$ of selected Produce for the global farming system, weighted averages

\begin{tabular}{l|l|l|l|l|l}
\hline Products & $\begin{array}{l}\text { Total virtual } \\
\text { water footprint } \\
\left(\mathrm{m}^{3} / \text { ton }\right)\end{array}$ & Products & $\begin{array}{l}\text { Total virtual } \\
\text { water footprint } \\
\left(\mathrm{m}^{3} / \text { ton }\right)\end{array}$ & Products & $\begin{array}{l}\text { Total virtual } \\
\text { water footprint } \\
\left(\mathrm{m}^{3} / \text { ton }\right)\end{array}$ \\
\hline Beef & 15,415 & $\begin{array}{l}\text { Maize } \\
(\mathrm{corn})\end{array}$ & 1222 & $\begin{array}{l}\text { Sweet } \\
\text { potatoes }\end{array}$ & 383 \\
\hline Pig meat & 5988 & $\begin{array}{l}\text { Rice, } \\
\text { paddy }\end{array}$ & 1673 & Beans, green & 561 \\
\hline $\begin{array}{l}\text { Chicken } \\
\text { meat }\end{array}$ & 4325 & Wheat & 1827 & $\begin{array}{l}\text { Groundnuts } \\
\text { shelled }\end{array}$ & 3974 \\
\hline Egg & 3265 & Manioc & 564 & Peas, green & 595 \\
\hline Milk & 1020 & Potatoes & 287 & Soya beans & 2145 \\
\hline Butter & 5553 & & & & \\
\hline $\begin{array}{l}\text { Milk } \\
\text { powder }\end{array}$ & 4745 & & & & \\
\hline
\end{tabular}

Source Mekonnen and Hoekstra (2012) 
People living in less privileged, food insecure areas, and a condition likely to also be present to 2030, will not be able to participate in the extension of the meat market and may still have restricted sources of proteins, currently at approximately $27 \mathrm{~g} /$ person/day proteins of plant origin and $28 \mathrm{~g} /$ person/day of animal origin.

\section{The Backup Source of Energy: Fat}

Fat and lipids are essential as nutrients for human survival and healthy life. Major oils which make up most of the global fat production are not only used as food ingredients but also for cosmetic and medical products. Palm, soya bean, and canola oils are used in large quantities as fuel. Such use has spurred the development of monocultures of oil producing plants. Prominent examples are oil palm plantations which have been expanded to some extent at the cost of virgin forests and peat lands, releasing large amounts of Greenhouse Gases and impairing biodiversity. The most produced and consumed oils are palm oil (35\%), soya bean oil (27\%), canola oil (16\%), and sunflower oil (9\%); oils from olives, cotton seed, corn, coconuts, sesame, and safflower seeds make up $13 \%$. Plant or cooking oils are liquid at room temperature with the exception of coconut and palm oil. In many countries specific preferences are observed with regard to the use of oil. Most oils are used in preparation of salad dressing and as ingredients in sauces, crèmes, and baking products. Oils with smoke points above $200{ }^{\circ} \mathrm{C}$ are especially suited for deep frying and include avocado oil, corn oil, olive oil, and sunflower oil; an important outlet for plant oils are margarines (Source Accessed: 2016-04-10).

Fig. 7 World fruit and vegetable production. Source IBISWorld Industry Report: Global Fruit \& Vegetables Processing, September 2015

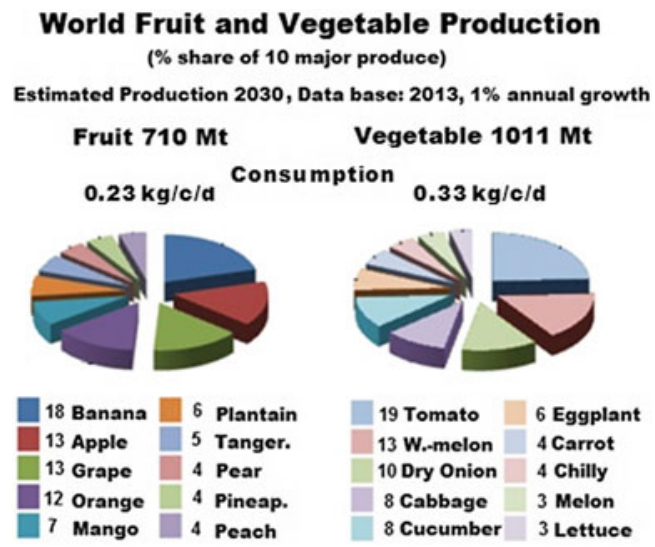


Table 5 Share of preservation processes of vegetable and fruit

\begin{tabular}{l|l|l|l|l}
\hline \multirow{2}{*}{} & \multicolumn{3}{|l}{ Process } & \multicolumn{3}{l}{} \\
\cline { 2 - 5 } & Canning & Freezing & Drying & Juice/precut vegetable ready-made salads \\
\hline Share $\%$ & 40 & 36 & 10 & 14 \\
\hline
\end{tabular}

Source IBISWorld industry report: global fruit and vegetables processing, September 2015

\section{Micronutrients-Nature's Wonder Drugs}

Micronutrients are key players in metabolism and maintaining tissue function and are required in small quantities. Macro- and micro-minerals as well as Vitamins and phyto-chemicals are needed lifelong with vegetables and fruits being the most important natural sources. Vegetables and fruits are processed and consumed in a variety of products according to their suitability (Fig. 7; Table 5).

In a world where place of production and place of consumption are increasingly distant from each other, food processing is essential especially for perishable food. Globally, canning or more technologically advanced heat preservation is the most widely used preservation method (Table 5). It is interesting to note that in countries with a traditionally high consumption of canned products, fresh fruits, and vegetables are gaining considerable market shares; on the other hand, canned products find a ready market in Developing Countries. A product category which comes close to canning is processing in flexible pouches, a process which is finding more and more applications especially for fruit and pasta preparations.

Clearly distinct from heat processing is packaging of slightly processed and/or simply trimmed products. Those products which are also partially packed under a gas atmosphere attract the health conscious consumer. Favorites are cut salads and fresh fruit preparations.

Increased consumption is also true for frozen products. With the expansion of the middle class in Developing Countries, the frozen food market expanded which was paralleled by increasing sales of home-freezers. In the industrialized countries the demand for semi-processed products is still growing. A reasonably priced alternative to intensively processed products are dried products. Mainly dried fruits together with nuts and to some extent dried vegetables and mushrooms are globally available.

Fig. 8 Share of global beverage sales. Source http:// www.statista.com/statistics/ 232773/forecast-for-globalbeverage-sales-by-beveragetype/World

\section{Share of Global Beverage Sales}

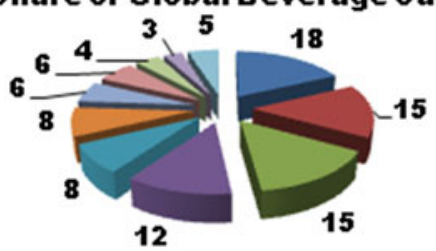

- Packaged water - Milk and milk drinks

iced tea n Bulk water

= Juice and juice drinks

= Carbonated drinks

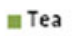

= Beer

= Coffee 


\section{Drinking}

A healthy diet not only consists of a sufficient food intake but also sufficient liquid intake, on the average roughly 1-2 L a day. On a global average of processed beverages, plain water is the most frequent potable liquid source followed by tea, milk, and juice, with the share of beer rather small at $8 \%$ (Fig. 8).

All together in 2013 about 794.6 billion liters of beverages were globally marketed to $7,136,796,000$ people. The average growth rate in the last few years was about $4.5-4.6 \%$. It is anticipated that the beverage market will develop at this pace in the near future. When global average consumption is broken down to daily consumption, the consumption of processed beverages per capita per day is about $0.3 \mathrm{~L}$. This figure is very hypothetical because especially in industrialized countries safe potable tap water is easily accessible; on the other hand, in Transition and Developing Countries large segments of the society are not able to participate in global market activities and have only limited access to potable water resources, either freely accessible or commercialized. Despite the many shortcomings, packaged water can be found in the most remote corners of the globe, a phenomenon which, in addition to the positive aspect that a safe potable water source is almost universally available, also has negative implications. The most obvious problem in the distribution of packaged potable water is that packaging materials must be disposed after usage. A second point is that processing/packaging generates costs which have to be recovered. For people living in limited financial conditions it means exclusion or even abstinence. A third point is that packaged materials have to be moved and transported which causes environmental stress especially if packaged water is transported around the globe. Finally, a point of serious concern is that packaging water is usually done by private companies which rely in most cases on privatized water resources. In many cases this is disadvantageous for local populations, for whom privatized water resources have been freely accessible over generations.

\section{Biofuel: A Threat to Food Security?}

In Developed and Developing Countries, worldwide pressure to reduce the emission of greenhouse gases has initiated legislation to introduce sustainable fuelsbiofuels - in the national array of power sources to partially substitute for classical combustible fossil fuels. For example, the EU has passed legislation setting a minimum target of $10 \%$ for biofuels within transport energy consumption by 2020 , and Malaysia has passed legislation that all diesel fuel sold in Malaysia must contain $5 \%$ palm oil.

Presently biofuels are produced largely from agricultural produce (Table 6). In the discussion on biofuel, however, the fact that considerable quantities of energy have to be invested for biofuel production itself and other negative effects are very 
Table 6 Feedstock requirements and land use for biofuel production

Feedstock requirements for $1000 \mathrm{~L}$ alcohol (ethanol) (average sugar/starch content, wet basis)/ bio-diesel and land area required

\begin{tabular}{l|l|l|l|l|l}
\hline $\begin{array}{l}\text { Produce } \\
\text { (product) }\end{array}$ & $\begin{array}{l}\text { Amount } \\
\mathrm{kg} / 10001 \\
\text { fuel }\end{array}$ & $\begin{array}{l}\text { Biofuel } \\
\text { production } \\
2030 \\
\text { (Billion L) }\end{array}$ & $\begin{array}{l}\text { Raw } \\
\text { material } \\
\text { equi. } \\
\text { (MMT) }\end{array}$ & $\begin{array}{l}\text { Spec. } \\
\text { requirements } \\
\text { (L/ha/year) }\end{array}$ & $\begin{array}{l}\text { Required } \\
\text { land } \\
\text { resources } \\
\left(\mathrm{km}^{2}\right)\end{array}$ \\
\hline $\begin{array}{l}\text { Maize } \\
\text { (ethanol) }\end{array}$ & 2350 & 68 & 156 & 1960 & 346,938 \\
\hline $\begin{array}{l}\text { Wheat } \\
\text { (ethanol) }\end{array}$ & 2700 & 68 & 190 & 952 & 714,287 \\
\hline $\begin{array}{l}\text { Sugar-beet } \\
\text { (ethanol) }\end{array}$ & 10,000 & 53 & 530 & 5060 & 104,743 \\
\hline $\begin{array}{l}\text { Sugarcane } \\
\text { (ethanol) }\end{array}$ & 11,000 & 53 & 689 & 4550 & 116,483 \\
\hline $\begin{array}{l}\text { Rapeseed } \\
\text { (bio-diesel) }\end{array}$ & 2700 & 38 & 102 & 954 & 595,611 \\
\hline $\begin{array}{l}\text { Biomass (to } \\
\text { liquid) } \\
\text { (bio-diesel) }\end{array}$ & 2000 & 57 & 114 & & \\
\hline $\begin{array}{l}\text { Cellulosic } \\
\text { materials } \\
\text { (Ethanol) }\end{array}$ & 3000 & 98 & 294 & 990 & \\
\hline
\end{tabular}

Source Vogelbusch (2008)

often hidden or neglected; this means that the entire biofuel production is not available for transportation energy. Major producers of biofuels are USA and Brazil for ethanol and the EU and Malaysia for bio-diesel.

To provide the necessary amounts of feedstock for biofuels, major agricultural areas traditionally used for production of cereals for food stock have been dedicated to the production of raw materials suited for the production of "first generation" biofuels. Current research is focused on efficiency of biofuel from these feed stocks and on other underutilized feedstock such as more complex biological materials like wood or algae, so called "second generation production." Given the complexity of these transformations, it may take 5 to 10 more years before this conversion will have a significant influence on biofuel production. Hopefully agricultural areas can at some future point in time again be available for food production.

The use of agricultural produce such as fruits and vegetables as feedstock for biofuel has provoked a discussion as to whether their extensive production would jeopardize food security especially in developing countries. However, estimates by FAO and other competent agencies conclude that our planet has capacity to provide food and feed stock for 12 billion people. Nonetheless, the use of edible produce for industrial purposes such as biofuel competes with consumption by humans and animals. With inadequate production, caused by, for example, unfavorable climatic conditions, prices escalate to levels which make it extremely difficult for the poor of the world society to cover its needs. 
Production pressure on land presently used for agricultural production can, of course, be alleviated by putting more land under production and increasing cropping frequency, using higher yielding species, and improving yields through improved agricultural methods. The limiting factor in all cases is the availability of water.

To produce the anticipated amounts of biofuel and the required additional agricultural production to feed the growing world population would require about 2 million $\mathrm{km}^{2}$ additional productive cultivated lands. Currently about 50 million $\mathrm{km}^{2}$ of the global land area of 130 million $\mathrm{km}^{2}$ can be used for agricultural purposes. About 14 million $\mathrm{km}^{2}$ are used as arable land, $33,585,676 \mathrm{~km}^{2}$ are used as permanent pastures and $1,537,338 \mathrm{~km}^{2}$ for permanent crops. Reserves which could be used for expanding agricultural land are mainly located in the Southern Hemisphere. For example, Brazil and other South American countries could contribute, and in Southern Africa Mozambique amongst others can contribute. In Asia reserve acreage is limited. On the other hand, China has the potential to expand its agricultural land if those areas can be sufficiently irrigated. In North America the lack of water is also the limiting factor. In Europe the land reserves are close to zero.

Availability of water is the Achilles heel in all efforts to expand agricultural production. Without the necessary water supply all efforts to expand agricultural production are in vain. The possibilities of extending the present irrigation practices are therefore limited since water resources of sufficient quality become scarce or too expensive to use for agricultural production. The problem will increase significantly in the future because of ongoing and accelerating climate change.

One action that needs to be taken is more efficient use of rainwater to enhance rain-fed agriculture. This requires more scientific attention. In addition, more stress-tolerant varieties of crop plants have to be developed through genetic engineering. All the factors with an impact on soil, water, climate and crop have to be focused on in more detail because they each play an important role in optimizing the use of rainwater.

\section{Conclusion}

In conclusion, there are clearly sufficient resources available to meet the needs of the growing world population for more food and to produce raw materials for the required amounts of biofuel to reduce global greenhouse gas emissions. Water continues to be a limiting natural resource but we are getting better at intelligent utilization of this invaluable resource. Data on the growth of the global population indicate that a moderate population increase is expected in the next twenty years; however, this increase and a slightly growing demand for biofuel can be absorbed by a more pronounced increase in agricultural production. Unfortunately expansion of agricultural production will not be uniformly distributed geographically. Increased production in industrialized and transitional countries is insufficient 
because of frequent production shortfalls in developing countries. As a result, major parts of the global society are not able to participate in an improved food supply or in increased standards of living. In the coming decades an improved food supply will not only rely on linear perpetuation of current exploitation of natural resources but also on intelligent and new approaches to solve existing problems. Many of these solutions are very simple and easy to implement such as using underutilized raw materials and food resources and initiating small-holder farmers in developing countries to grow biofuel crops such as Jatropha (Jatropha curcas) or Pongam (Pongamia pinnata). Some of this production can occur on underutilized land to improve their financial situation by generating cash income. Other more sophisticated solutions are waiting in the Silicon Valleys around the globe for their utilization, solutions like in vitro-meat or fruit-based vaccines and similar approaches. Although rational thinking and reliance on science are essential for solutions, social distortions and imbalances coupled with religious and ideological intolerance, hate, and lack of education and insight must be addressed and resolved. Thus the solutions require not only science but also fundamental changes in the social dimensions.

\section{References}

Alexandratos, N., \& Bruinsma, J. (2012). World agriculture towards 2030/2050: The 2012 revision. ESA Working paper No. 12-03, FAO, Rome.

FAO. (1996). Rome Declaration on World Food Security and World Food Summit Plan of Action. World Food Summit. 13-17 Nov 1996, Rome

Mekonnen, M. M., \& Hoekstra, A. Y. (2012). A global assessment of the water footprint of farm animal product. Ecosystems, 15, 401-415.

Vogelbusch. (2008). The state of food and agriculture: Biofuels. Prospects, risks and opportunities FAO, Rome. http://www.bioethanol.vogelbusch.com/en/faq.php

Open Access This chapter is distributed under the terms of the Creative Commons Attribution 4.0 International License (http://creativecommons.org/licenses/by/4.0/), which permits use, duplication, adaptation, distribution and reproduction in any medium or format, as long as you give appropriate credit to the original author(s) and the source, provide a link to the Creative Commons license and any changes made are indicated.

The images or other third party material in this chapter are included in the work's Creative Commons license, unless indicated otherwise in the credit line; if such material is not included in the work's Creative Commons license and the respective action is not permitted by statutory regulation, users will need to obtain permission from the license holder to duplicate, adapt or reproduce the material.

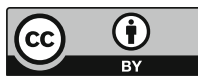




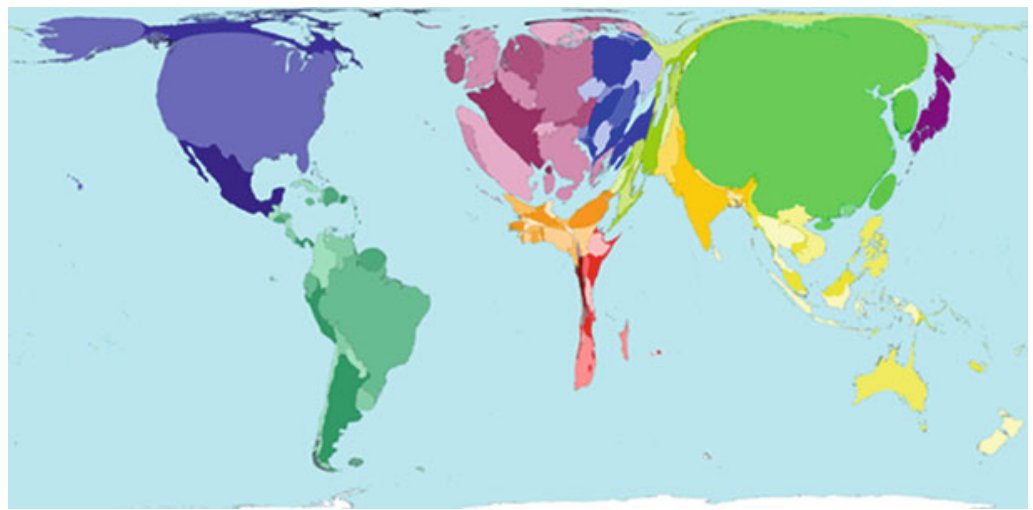

Meat production. China, the United States and Brazil produce the most meat in the world. Together these three territories produce half of all the meat that is produced in the world. Territory size shows the proportion of worldwide meat production that occurs there. Source www.worldmapper.org. Published with kind permission of (C) Copyright Benjamin D. Hennig (Worldmapper Project)

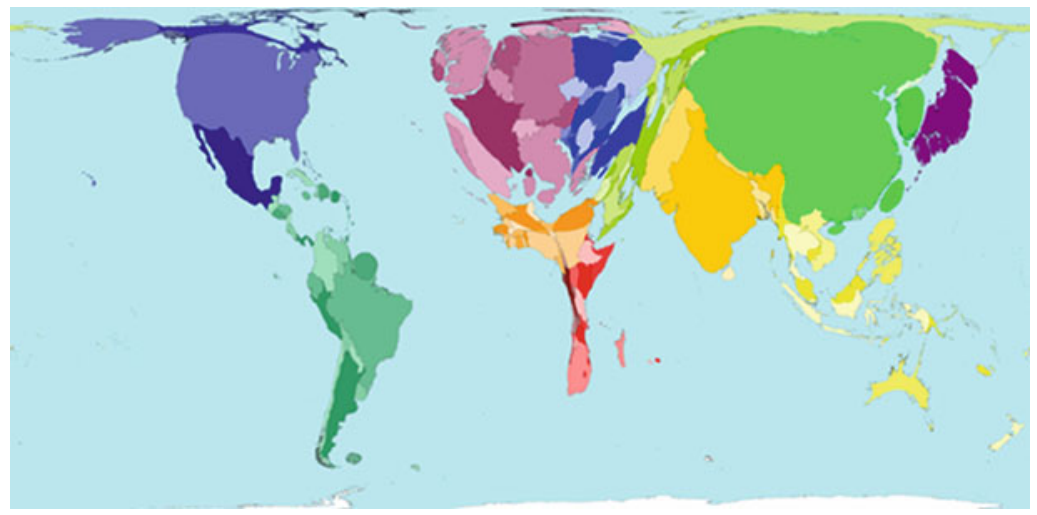

Meat consumption. Meat, as shown here, refers to all animal products that are consumed by people. Meat consumption per person is highest in Western Europe, while the most meat is consumed in China, a quarter of the world total. Territory size shows the proportion of worldwide meat (including animal products) consumption that occurs there. Source www. worldmapper.org. Published with kind permission of (C) Copyright Benjamin D. Hennig (Worldmapper Project) 